\title{
Effect of ocean acidification on marine fish sperm (Baltic cod: Gadus morhua)
}

\author{
A. Y. Frommel ${ }^{1}$, V. Stiebens ${ }^{1}$, C. Clemmesen ${ }^{1}$, and J. Havenhand ${ }^{2}$ \\ ${ }^{1}$ Leibniz-Institute of Marine Sciences IFM-GEOMAR, Duesternbrooker Weg 20, 24105 Kiel, Germany \\ ${ }^{2}$ Dept. of Marine Ecology - Tjärnö, University of Gothenburg 45296 Strömstad, Sweden
}

Received: 22 June 2010 - Published in Biogeosciences Discuss.: 5 August 2010

Revised: 17 November 2010 - Accepted: - Published: 1 December 2010

\begin{abstract}
Ocean acidification, as a consequence of increasing marine $p \mathrm{CO}_{2}$, may have severe effects on the physiology of marine organisms. However, experimental studies remain scarce, in particular concerning fish. While adults will most likely remain relatively unaffected by changes in seawater $\mathrm{pH}$, early life-history stages are potentially more sensitive - particularly the critical stage of fertilization, in which sperm motility plays a central role. In this study, the effects of ocean acidification (decrease of $\mathrm{pH}_{T}$ to 7.55) on sperm motility of Baltic cod, Gadus morhua, were assessed. We found no significant effect of decreased $\mathrm{pH}$ on sperm speed, rate of change of direction or percent motility for the population of cod analyzed. We predict that future ocean acidification will probably not pose a problem for sperm behavior, and hence fertilization success, of Baltic cod.
\end{abstract}

\section{Introduction}

Atmospheric $\mathrm{CO}_{2}$ levels are currently rising faster than at any time in the previous 21 million years, driven largely by anthropogenic activities such as burning of fossil fuels and changes in land-use (IPCC, 2007). As the oceans are in a slow but continuous equilibrium with the atmosphere, it is projected that corresponding increases in $\mathrm{CO}_{2}$ absorption by the ocean from the atmosphere will lead to a drop in $\mathrm{pH}$ of $\leq 0.4$ units by the year 2100 (Caldeira and Wickett, 2003; IPCC, 2007). This will in turn cause an under-saturation of calcium carbonate (Feely et al., 2004), which could have pervasive effects on calcifying marine organisms such

Correspondence to: A. Y. Frommel (afrommel@ifm-geomar.de) as molluscs, cnidarians, and echinoderms (Fabry et al., 2008; Doney et al., 2009). In addition, elevated $\mathrm{CO}_{2}$ concentrations can disturb the acid-base regulation, blood circulation, and respiration, as well as the nervous system of marine organisms, leading to long term effects such as reduced growth rates and reproduction (Pörtner et al., 2004).

Adult fish are thought to be relatively insensitive to low seawater $\mathrm{pH}$ because they have effective acid-base regulatory systems, whereas early life stages such as eggs and larvae have not yet fully developed these regulatory processes and could therefore be affected (Morris, 1989; Sayer et al., 1993). The majority of fish are external fertilizers, and sperm are activated by seawater as they are expelled into the open ocean during a spawning event (Westin and Nissling, 1991). While there is not much knowledge on the effects of ocean acidification on fish sperm, some experiments have been performed on invertebrate sperm, with differing results even between closely related species (Kurihara and Shirayama, 2004; Kurihara et al., 2007, 2009; Havenhand et al., 2008; Havenhand and Schlegel, 2009; Kurihara et al., 2009). Studies of the effects of acidification by mineral acids on sperm swimming in fish (e.g. rainbow trout; Baynes et al., 1981) have found motility to be inhibited below $\mathrm{pH} 7.8$ (an effect that can be overcome by addition of $\mathrm{Ca}^{2+}$ and $\mathrm{Mg}^{2+}$ ions). Billard and Cosson (1988) found the beat frequency (proportional to speed) of spermatozoa to be dependent on the $\mathrm{pH}$ of the swimming solution in trout, while for other species such as carp (Marian et al., 1997), sturgeon (Gallis, 1991; Linhart et al., 1995) and paddlefish (Cosson and Linhart, 1996) acidic conditions have been shown to reduce sperm motility. In contrast, Stoss (1983) found no effect of $\mathrm{pH}$ on motility but a reduction in the short-term viability of salmonid sperm.

Published by Copernicus Publications on behalf of the European Geosciences Union. 
It therefore seems likely that reductions in seawater $\mathrm{pH}$ mediated by increasing levels of atmospheric $\mathrm{CO}_{2}$ could have a substantial effect on the sperm motility - and hence fertilization success - of key marine fish species. Cod is one of the key fish species in the Baltic ecosystem. Its recruitment strength in the Baltic varies greatly from year to year as a result of variation in spawning efficiency as well as gamete and larval survival (Grauman, 1973; Houde, 2008). These early life-history stages are the most sensitive to abiotic conditions such as salinity and oxygen availability (Westin and Nissling, 1991). The extent to which ocean acidification might influence sperm swimming behavior of Baltic cod is examined in this study.

\section{Methods}

Adult cod were caught from the R/V Alkor in several hauls in the spawning grounds of the Bornholm Basin, Baltic Sea, during a cruise in August 2009. Ripe males were picked out immediately after catch and stripped just prior to analysis. Sperm were collected in dry glass vials and held on ice. Contamination of sperm with urine or feces was carefully avoided. The seawater used in experiments was filtered $(0.1 \mu \mathrm{m})$, UV sterilized and had a salinity of 17.4. Seawater was pre-bubbled in order to reach a $\mathrm{CO}_{2}$ partial pressure $\left(p \mathrm{CO}_{2}\right)$ of 380 and $1400 \mu$ atm and kept in closed Nalgene ${ }^{\circledR}$ containers (preliminary trials showed that the carbonate chemistry was unaltered for at least a week). The $\mathrm{pH}$ of the water was monitored throughout each trial with a pH-meter (WTW) calibrated with National Bureau of Standards (N.B.S.) buffers. Total alkalinity $\left(A_{\mathrm{T}}\right)$ and dissolved inorganic carbon $\left(C_{\mathrm{T}}\right)$ were measured on subsamples and the carbonate system was calculated from $C_{\mathrm{T}}$ and $A_{\mathrm{T}}$ using $\mathrm{CO}_{2} \mathrm{SYS}$ (Lewis and Wallace, 1998). All experiments were conducted at a room temperature around $8^{\circ} \mathrm{C}$ (with drift up to $9.5^{\circ} \mathrm{C}$ ), while the sperm was held on ice before use.

Sperm suspensions were created by activating $10 \mu \mathrm{l}$ "dry" sperm (without previous contact to any water) from a single male in $4 \mathrm{ml}$ of filtered seawater (control or elevated $p \mathrm{CO}_{2}$ ). One drop of sperm suspension was then placed onto a glass microscope slide inside an O-ring of $1 \mathrm{~mm}$ thickness and covered with a coverslip, to minimize wall-effects (Havenhand et al., 2008). To prevent sperm from adhering to the glass surfaces, slides and cover slips were pre-coated with bovine serum albumin (see Bolton and Havenhand, 1994). Sperm swimming behavior was recorded (within $10 \mathrm{~s}$ after activation) using a digital camera (Canon IXUS, $3.0 \mathrm{x}$ digital zoom) mounted onto a microscope (Leitz Laborlux K, $10 \mathrm{x}$ objective). For each fish, video was obtained from each of 5 replicate slides using control $\left(\mathrm{pH}_{T}=8.08\right)$ and acidified seawater $\left(\mathrm{pH}_{T}=7.55\right)$. Video clips $(3 \mathrm{~s}$ duration) were analyzed using CellTrak1.3 ${ }^{\circledR}$ (Motion Analysis Corporation, Santa Rosa, CA). Looking at an average of 200 tracks per slide, the average swimming speed and the percentage of motile sperm was determined for each replicate for all 18 males.

\section{Data analysis}

Assumptions of normality and homogeneity of variance were checked using Kolmogorov-Smirnoff and Levene's test, and yielded no difference among treatments. The effect of $\mathrm{pH}$ across different males was tested by two-factorial mixed-model analysis of variance (ANOVA), using Statistica 6.1 (StatSoft, Inc).

\section{Results}

Mean $\mathrm{pH}$ (calculated with $\mathrm{CO}_{2} \mathrm{SYS}$ ) in the control and elevated $p \mathrm{CO}_{2}$ conditions was 8.080 and 7.558 , respectively (Table 1). Males ranged in total length from 36 to $50 \mathrm{~cm}$ (356 to $991 \mathrm{~g}$; Table 2). The average sperm swimming speeds and percent sperm motility differed greatly between the males, as did the difference between the treatment and controls (Table 2), however these differences were size independent. Sperm swimming behavior was marginally faster and of higher motility in control treatment than at low $\mathrm{pH}$, but these differences were very small (Fig. 1). ANOVA showed that responses of sperm to reduced $\mathrm{pH}$ differed significantly between males for all parameters measured, however there was no significant effect of $\mathrm{pH}$ on either speed or percent motility, and no significant interactions between male and treatment (Table 3). Therefore, we cannot reject the null hypothesis of $\mathrm{CO}_{2}$ having no effect on the sperm in the parameters measured.

\section{Discussion}

No effect of $\mathrm{CO}_{2}$-induced ocean acidification was found on the sperm behaviour of Baltic Sea cod (speed and percent motility; Table 2). Some authors have interpreted equivalent non-significant results in ocean acidification experiments as evidence for no effect of acidification (e.g. Byrne et al., 2009). This is inappropriate statistical practice as it is well established that non-significant results are simply inconclusive (Fisher, 1935; Nakagawa and Foster, 2004). Valuable insight on the likelihood that the null-hypothesis (of no effect) is correct can, however, be provided by confidence intervals around statistical effect sizes (Nakagawa and Foster, 2004). Using the methodology of Hedges and Olkin (1985) we calculated effect sizes and 95\% confidence intervals around effect sizes for sperm speed and percent motility. These showed clear overlap with zero, (effect size $[ \pm 95 \% \mathrm{CI}]$ for sperm speed $=-0.165 \pm 0.654$, and for percent motility $=-0.247 \pm 0.656$ ). Consequently we conclude that sperm swimming behaviour (and therefore fertilization success) in Baltic cod is likely to be robust 
Table 1. Summary of carbon system parameters: $A_{\mathrm{T}}$, total alkalinity, $C_{\mathrm{T}}$, total dissolved inorganic carbon (both measured), $p \mathrm{CO}_{2}$, partial pressure of $\mathrm{CO}_{2}$, calculated $\mathrm{pH}_{T}$ (total scale), $T$, Temperature and $S$, Salinity.

\begin{tabular}{lccrccc}
\hline treatment & $\begin{array}{c}A_{\mathrm{T}} \\
\left(\mu \mathrm{mol} \mathrm{kg}^{-1} \mathrm{SW}\right)\end{array}$ & $\begin{array}{c}C_{\mathrm{T}} \\
\left(\mu \mathrm{mol} \mathrm{kg}^{-1} \mathrm{SW}\right)\end{array}$ & $\begin{array}{c}p \mathrm{CO}_{2} \\
(\mu \mathrm{ratm})\end{array}$ & $\mathrm{pH}$ & $\begin{array}{c}T \\
\left({ }^{\circ} \mathrm{C}\right)\end{array}$ & $S$ \\
\hline acidified & 2024.4 & 2055.2 & 1364.8 & 7.558 & 9.4 & 17.4 \\
control & 2068.8 & 1973.4 & 390.8 & 8.080 & 9.4 & 17.4 \\
\hline
\end{tabular}

Table 2. Sperm swimming behavior in control $(\mathrm{C})$ and acidified $(\mathrm{A})$ conditions. Speed $=$ mean sperm swimming speed $\left.(\mu \mathrm{m} \mathrm{s})^{-1}\right) ; \%$ mot. $=$ percent motile sperm.

\begin{tabular}{crrrrrrrc}
\hline $\begin{array}{c}\text { Fish } \\
\text { number }\end{array}$ & $\begin{array}{r}\text { Length } \\
(\mathrm{cm})\end{array}$ & $\begin{array}{r}\text { Weight } \\
(\mathrm{g})\end{array}$ & Speed C & Speed A & $\Delta$ speed & $\%$ mot. C & $\%$ mot. A & $\Delta \%$ mot. \\
\hline 1 & 36 & 356 & 66.81 & 58.68 & 8.12 & 89.14 & 84.35 & 4.79 \\
2 & 37 & 382 & 67.54 & 68.46 & -0.93 & 85.88 & 81.63 & 4.25 \\
3 & 47 & 779 & 37.49 & 34.57 & 2.92 & 71.07 & 70.96 & 0.11 \\
4 & 46 & 782 & 49.71 & 51.91 & -2.19 & 74.43 & 75.29 & -0.85 \\
5 & 39 & 429 & 52.00 & 40.48 & 11.52 & 80.44 & 76.85 & 3.59 \\
6 & 38 & 445 & 42.92 & 45.89 & -2.97 & 79.54 & 81.64 & -2.10 \\
7 & 40 & 541 & 55.59 & 62.28 & -6.69 & 78.85 & 82.99 & -4.14 \\
7 & 40 & 533 & 63.04 & 64.97 & -1.93 & 73.97 & 75.10 & -1.12 \\
9 & 46 & 887 & 73.25 & 70.19 & 3.06 & 78.14 & 80.11 & -1.97 \\
10 & 41 & 511 & 44.87 & 39.97 & 4.90 & 76.81 & 69.02 & 7.78 \\
11 & 41 & 636 & 60.90 & 54.91 & 5.99 & 85.19 & 82.60 & 2.59 \\
12 & 43 & 571 & 68.72 & 61.76 & 6.97 & 83.59 & 76.75 & 6.84 \\
13 & 40 & 550 & 63.88 & 62.01 & 1.87 & 85.61 & 89.83 & -4.22 \\
14 & 48 & 759 & 56.55 & 62.30 & -5.75 & 81.27 & 81.82 & -0.56 \\
15 & 48 & 809 & 56.10 & 45.43 & 10.68 & 87.49 & 83.97 & 3.52 \\
16 & 40 & 462 & 88.71 & 85.75 & 2.96 & 92.07 & 88.76 & 3.31 \\
17 & 50 & 991 & 51.59 & 49.70 & 1.89 & 83.97 & 79.94 & 4.03 \\
18 & 41 & 537 & 55.23 & 59.51 & -4.27 & 85.72 & 56.48 & -0.76 \\
\hline Mean & 42 & 609 & 58.61 & 56.60 & 2.01 & 81.84 & 80.45 & 1.39 \\
S.D. & 4 & 183 & 12.14 & 12.63 & 5.40 & 5.65 & 5.63 & 3.59 \\
\hline
\end{tabular}

Table 3. ANOVA results of effect of $\mathrm{CO}_{2}$ "treatment" (fixed) and male (random) on sperm swimming speed and \% motility along with the interaction of treatment $\times$ male.

\begin{tabular}{lrrrrrr}
\hline average speed & $\begin{array}{r}\text { MS } \\
\text { Effect }\end{array}$ & $\begin{array}{r}\text { df } \\
\text { Error }\end{array}$ & $\begin{array}{r}\text { MS } \\
\text { Error }\end{array}$ & $F$ & $p$ & $r$ \\
treatment & 140.79 & 18.62 & 73.41 & 2.02 & 0.18 & 0.32 \\
male & 1437.29 & 16.72 & 69.48 & 20.69 & 0.00 & 0.73 \\
treatment $\times$ male & 69.64 & 139.00 & 94.97 & 0.73 & 0.76 & 0.20 \\
\hline$\%$ motility & & & & & & \\
\hline treatment & 93.29 & 17.57 & 31.88 & 2.99 & 0.10 & 0.38 \\
male & 281.94 & 16.77 & 31.16 & 9.05 & 0.00 & 0.58 \\
treatment $\times$ male & 31.18 & 139.00 & 34.63 & 0.90 & 0.57 & 0.22 \\
\hline
\end{tabular}

www.biogeosciences.net/7/3915/2010/ to near-future changes in ocean $\mathrm{pH}$ arising as a result of increasing atmospheric $\mathrm{CO}_{2}$.

Changes in ionic concentration and osmolality are known to trigger sperm motility in teleost fish sperm (Morisawa and Suzuki, 1980). Once sperm are released into the environment, the external $\mathrm{pH}$ is of crucial importance as it influences intracellular proton concentration, depolarization of the cell membrane, and therefore sperm motility (Alavi and Cosson, 2005; Alavi and Cosson, 2006). The $\mathrm{pH}$ of cod seminal fluid lies between 7.9 to 8.4 (Suquet et al., 2005) and therefore, lowering the $\mathrm{pH}$ of the surrounding activating fluid to 7.55 could inhibit the triggering of sperm motility, as the optimum $\mathrm{pH}$ of the activation medium has been found to be about one unit higher than the $\mathrm{pH}$ of the seminal fluid in other fish species (Alavi and Cosson, 2005).

The methods by which $\mathrm{pH}$ was manipulated in these studies can have substantial influence on the results: reducing 

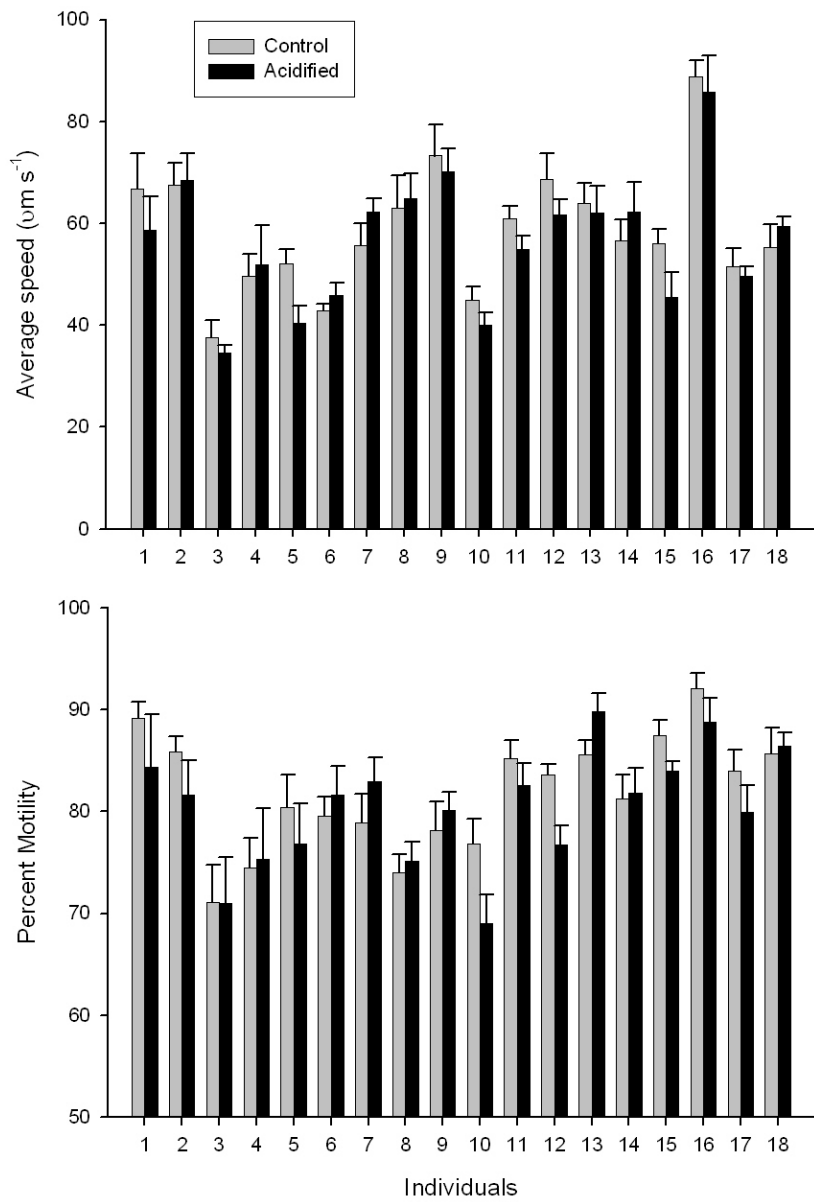

Fig. 1. Individual variability between males (1-18) in control (grey) and acidified (black) treatments for sperm swimming speed and percent motile sperm. Error bars denote the standard deviation from the mean between the five replicates.

$\mathrm{pH}$ by the addition of $\mathrm{NH}_{4} \mathrm{Cl}$ had little effect on the activation of fish sperm (Alavi and Cosson, 2005) whereas $\mathrm{CO}_{2}$-induced $\mathrm{pH}$ reductions in the seminal fluid of flat fish inhibit the flagellar movement of the sperm (Billard et al., 1993; Dreano et al., 1995; Inaba et al., 2003). This latter effect is due to carbonic anhydrase (CA), a strong $\mathrm{pH}$ regulator, which catalyzes the conversion of $\mathrm{CO}_{2}$ to $\mathrm{HCO}_{3}^{-}$, which in turn acts as an inhibitor for fish sperm. The $\mathrm{CO}_{2} / \mathrm{HCO}_{3}^{-}$mechanism possibly evolved in flat fish to prevent spontaneous activation of sperm in the seminal fluid (Inaba et al., 2003). While CA is present in abundance in flatfish, most other teleost species do not have major proteins in their seminal fluid and therefore do not have this problem of concentrating motility inhibiting ions (Inaba et al., 2003).

The question why Baltic cod sperm are seemingly unaffected by acidified seawater is an intriguing one. High $\mathrm{CO}_{2}$ (and correspondingly low $\mathrm{pH}$ ) levels are common in their environment and it is therefore probable that they have adapted to these extreme conditions. The Baltic Sea is a unique system: it is enclosed with relatively poor circulation, has a low salinity and does not exchange much with the North Sea. Further, it is highly eutrophic, such that the deep waters are often depleted in oxygen and exhibit high $p \mathrm{CO}_{2}$ and hence low $\mathrm{pH}$ (Kuss et al., 2006; Omstedt et al., 2009). During the spawning season, Baltic cod spend most of their time in waters with a salinity of at least 12 and oxygen levels above $4 \mathrm{mll}^{-1}$ (Schaber et al., 2009), limits that also determine egg survival. In August 2009, these conditions corresponded to depths between 50 and $64 \mathrm{~m}$ where we measured $\mathrm{pH}_{\mathrm{NBS}}$ values between 7.4 and 7.9. Therefore, newly spawned gametes and eggs may already be experiencing the acidification conditions predicted in future scenarios for the open ocean. The next step is to test whether North Sea cod, which spawn in well-oxygenated, low $p \mathrm{CO}_{2}$, surface waters are affected in their sperm motility by acidified seawater. The results will be central to determining the adaptive capacity of cod, and the likelihood that the crucial process of fertilization will be robust to future changes in ocean $\mathrm{pH}$.

Acknowledgements. This paper is a contribution to the "European Project on Ocean Acidification" (EPOCA) which received funding from the European Community's Seventh Framework Programme (FP7/2007-2013) under grant agreement N211384. It was also supported by the nationally coordinated project entitled "Biological Impacts of Ocean ACIDification" (BIOACID), funded by the German Ministry for Education and Research (BMBF). This work was partly performed within the Linnaeus Centre for Marine Evolutionary Biology (http://www.cemeb.science.gu.se/), and supported by a Linnaeus-grant from the Swedish Research Councils VR and Formas.

Edited by: J.-P. Gattuso

\section{References}

Alavi, S. M. H. and Cosson, J.: Sperm motility and fertilizing ability in the Persian sturgeon Acipenser persicus, Aquac. Res. 36, 841-850, 2005.

Alavi, S. M. H. and Cosson, J.: Sperm motility in fishes (I) Effects of temperature and pH: A review, Cell Biol. Int., 29, 101-110, 2005.

Alavi, S. M. H. and Cosson, J.: Sperm motility in fishes. (II) Effects of ions and osmolality: A review, Cell Biol. Int., 30, 1-14, 2006.

Baynes, S. M., Scott, A. P., and Dawson, A. P.: Rainbow trout, Salmo gairdnerii richardson, spermatozoa - effects of cations and pH on motility, J. Fish Biol., 19, 259-267, 1981.

Billard, R. and Cosson, J.: Sperm motility in rainbow trout, Parasalmo gairdneri; effects of $\mathrm{pH}$ and temperature, in: Reproduction in fish: basic and applied aspects in endocrinology and genetics, edited by: Breton, B. and Zohar, Y., Inra, Paris, 161-167, 1988.

Billard, R., Cosson, J., and Crim, L. W.: Motility and survival of halibut sperm during short term storage, Aquat. Living Resour., 6, 67-75, 1993.

Byrne, M., Ho, M., Selvakumaraswamy, P., Nguyen, H. D., Dworjanyn, S. A., and Davis, A. R.: Temperature, but not 
$\mathrm{pH}$, compromises sea urchin fertilization and early development under near-future climate change scenarios, P. Roy. Soc. B-Biol. Sci., 276(1663), 1883-1888, 2009.

Caldeira, K. and Wickett, M. E.: Anthropogenic carbon and ocean pH, Nature, 425, 365-365, 2003.

Cosson, J. and Linhart, O.: Paddlefish, Polyodon spathula, spermatozoa: Effects of potassium and $\mathrm{pH}$ on motility, Folia Zool., 45, 361-370, 1996.

Cosson, J., Groison, A. L., Suquet, M., Fauvel, C., Dreanno, C., and Billard, R.: Studying sperm motility in marine fish: An overview on the state of the art, J. Appl. Ichthyol., 24, 460-486, 2008.

Doney, S. C., Fabry, V. J., Feely, R. A., and Kleypas, J. A.: Ocean acidification: The other $\mathrm{CO}_{2}$ problem, Annu. Rev. Mar. Sci., 1, 169-192, 2009.

Dreano, C., Suquet, M., Cosson, J., Cibert, C., Huignard, H., and Billard, R.: $\mathrm{CO}_{2}$ effects on flagella of native and demembranated turbot spermatozoa, at the International Symposium on Reproductive Physiology of Fish, University of Texas at Austin, Austin Tx., 2-8 July, p. 5, 1995.

Fabry, V. J., Seibel, B. A., Feely, R. A., and Orr, J. C.: Impacts of ocean acidification on marine fauna and ecosystem processes, ICES J. Mar. Sci., 65, 414-432, 2008.

Feely, R. A., Sabine, C. L., Lee, K., Berelson, W., Kleypas, J., Fabry, V. J., and Millero, F. J.: Impact of anthropogenic $\mathrm{CO}_{2}$ on the $\mathrm{CaCO}_{3}$ system in the oceans, Science, 305, 362-366, 2004.

Fisher, R. A.: The design of experiments, Oliver and Boyd, Edinburgh, 1935.

Gallis, J. L., Fedrigo, E., Jatteau, P., Bonpunt, E., and Billard, R.: Siberian sturgeon, Acipenser baeri, spermatozoa: effects of dilution, $\mathrm{pH}$, osmotic pressure, sodium and potassium ions on motility, edited by: Williot, P., Cemagref, Borgeaux, 143-151, 1991.

Gattuso, J.-P. and Lavigne, H.: Technical Note: Approaches and software tools to investigate the impact of ocean acidification, Biogeosciences, 6, 2121-2133, doi:10.5194/bg-6-2121-2009, 2009.

Grauman, G. B.: Investigations of factors influencing fluctuations in abundance of Baltic cod, Rap. Proces., 146, 73-76, 1973.

Havenhand, J. N., Buttler, F. R., Thorndyke, M. C. and Williamson, J. E.: Near-future levels of ocean acidification reduce fertilization success in a sea urchin, Curr. Biol., 18, R651-R652, 2008.

Havenhand, J. N. and Schlegel, P.: Near-future levels of ocean acidification do not affect sperm motility and fertilization kinetics in the oyster Crassostrea gigas, Biogeosciences, 6, 3009-3015, doi:10.5194/bg-6-3009-2009, 2009.

Hedges, L. V. and Olkin, I.: Statistical methods for meta-analysis, Academic Press, Orlando, FL, 369, 1985.

Houde, E. D.: Emerging from Hjort's Shadow, J. Northwest. Atl. Fish. Sci. 41, 53-70, 2008.

Inaba, K., Dreanno, C., and Cosson, J.: Control of flatfish sperm motility by $\mathrm{CO}_{2}$ and carbonic anhydrase, Cell Motil. Cytoskel., 55, 174-187, 2003.

IPCC. Climate Change 2007: The physical science basis, Contribution of working group I to the fourth assessment report of the intergovernmental panel on climate change, edited by: Solomon, D. Q. S., Manning, M., Chen, Z., Marquis, M., Averyt, K. B., Tignor, M., and Miller, H. L., Cambridge, CUP, 2007.

Kurihara, H., Asai, T., Kato, S., and Ishimatsu, A.: Effects of elevated $p \mathrm{CO}_{2}$ on early development in the mussel Mytilus galloprovincialis, Aquat. Biol., 4, 225-233, 2009.

Kurihara, H., Kato, S., and Ishimatsu, A.: Effects of increased seawater $p \mathrm{CO}_{2}$ on early development of the oyster Crassostrea gigas, Aquat. Biol. 1, 91-98, 2007.

Kurihara, H. and Shirayama, Y.: Effects of increased atmospheric $\mathrm{CO}_{2}$ on sea urchin early development, Mar. Ecol. Prog. Ser., 274, 161-169, 2004.

Kuss, J., Roeder, W., Wlost, K. P., and DeGrandpre, M. D.: Time-series of surface water $\mathrm{CO}_{2}$ and oxygen measurements on a platform in the central Arkona Sea (Baltic Sea): Seasonality of uptake and release, Mar. Chem., 101, 220-232, 2006.

Lewis, E. and Wallace, D. W. R.: Program Developed for $\mathrm{CO}_{2}$ Systems Calculations, ORNL/CDIAC-105, Carbon Dioxide Information Analysis Centre, Oak Ridge National Laboratory, US Department of Energy, Oak Ridge, Tennessee, 1998.

Linhart, O., Mims, S. D., and Shelton, W. L.: Motility of spermatozoa from shovelnose sturgeon and paddlefish, J. Fish Biol., 47, 902-909, 1995.

Marian, T., Krasznai, Z., Balkay, L., Emri, M., and Tron, L.: Role of extracellular and intracellular $\mathrm{pH}$ on carp sperm motility and modifications by hyperosmosis of regulation of the $\mathrm{Na}+\mathrm{H}+$ exchanger, Cytometry, 27, 374-382, 1997.

Morisawa, M. and Suzuki, K.: Osmolality and potassium-ion - their roles in initiation of sperm motility in teleosts, Science, 210, 1145-1147, 1980.

Morris, R., Taylor, E. W., Brown, D. J. A., and Brown, J. A.: Acid Toxicity and Aquatic Animals, Cambridge University Press, Cambridge, Society for experimental biology seminar series No. 34, 1989.

Nakagawa, S. and Foster, T. M.: The case against retrospective statistical power analyses with an introduction to power analysis, Acta. Ethol., 7, 103-108, 2004.

Omstedt, A., Gustafsson, E., and Wesslander, K.: Modelling the uptake and release of carbon dioxide in the Baltic sea surface water, Cont. Shelf Res., 29, 870-885, 2009.

Pörtner, H. O., Langenbuch, M., and Reipschlaeger, A.: Biological impact of elevated ocean $\mathrm{CO}_{2}$ concentration: Lessons from animal physiology and earth history, J. Oceanogr., 60, 705-718, 2004.

Sayer, M. D. J., Reader, J. P., and Dalziel, T. R. K.: Fresh-water acidification - effects on the early-life stages of fish, Rev. Fish Biol. Fisher., 3, 298-298, 1993.

Schaber, M., Hinrichsen, H.-H., Neuenfeldt, S., and Voss, R.: Hydroacoustic resolution of small-scale vertical distribution in Baltic cod Gadus morhua - habitat choice and limits during spawning, Mar. Ecol. Prog. Ser., 377, 239-253, 2009.

Stoss, J.: Fish gamete preservation and spermatozoan physiology, in: Fish Physiology Vol. IX B., edited by: Hoar, W. S., Randall, D. J., and Donaldson, E. M., Academic Press, New York, 305350, 1983.

Suquet, M. R., Cosson, C., Severe, J., Quemener, A., Fauvel, L., and Cibert C.: Changes in Atlantic cod (Gadus morhua) sperm quality with time, Eur. Aquac. Soc. (Special Publication No.), 36, 503-505, 2005.

Westin, L. and Nissling, A.: Effects of salinity on spermatozoa motility, percentage of fertilized-eggs and egg development of Baltic cod (Gadus morhua), and implications for cod stock fluctuations in the Baltic, Mar. Biol., 108, 5-9, 1991. 